\title{
नेपाली बालउपन्यासमा प्रस्तुत सपनाको विश्लेषण
}

\author{
राजेन्द्र खनाल \\ sauravabhirk@gmail.com \\ उपप्राध्यापक \\ शिक्षाशास्त्र केन्द्रीय विभाग, त्रि.वि., कीर्तिपुर
}

लेखसार

नेपाली बालउपन्यासमा प्रस्तुत सपनाको विश्लेषण गर्नु यस लेखको प्रमुख उद्देश्य हो। पुस्तकालयीय अध्ययन प्रक्रियाबाट तथ्य सङ़कलन गरी नेपाली बालउपन्यासलाई प्राथमिक सामग्रीका रूपमा उपयोग गरिएको छ। बालमनोविज्ञान तथा सपनासंग सम्बन्धित विभिन्न सैद्धान्तिक पुस्तकहरूलाई द्वितीयक सामग्रीका रूपमा लिइएको यस लेखमा वर्णनात्मक विधिको उपयोग गरिएको छ। नेपाली बालउपन्यासमा सपनाका सन्दर्भलाई बालमनोवैज्ञानिक पक्षसँग सम्बन्धित गरी स्वाभाविक तरिकाबाट प्रस्तुत गरिएको छ। नेपाली बालजपन्यासमा सामाजिक परिवेश तथा संरचनाको प्रभाव बालमस्तिष्कमा परेको र तिनले सपनाका माध्यमबाट अभिव्यक्त गरेको देखाइएको छ। बालबालिकाहरूले आफले चाहेका विषय वा वस्तु प्राप्त गर्न नसक्दा सपनाका माध्यमवाट इच्छापर्ति गरेको देखाइएको छ। त्यस्तै उनीहरूले आफूले भोगेका पीडा तथा अपमानको पनि बदला सपनामा नै लिएर सन्तुष्ट भएको सड्केत गर्दै बालमनोवैज्ञानिक पक्षको सघन उठान गरिएको छ। बालवालिकाहरू साथीहरूबिचका प्रेम, ईष्या, खुसी, रिस आदि संवेग पनि बालवालिकाले सपनामा देखेका सन्दर्भ पनि नेपाली बालउपन्यासमा व्यक्त भएका छन । नेपाली बालउपन्यासमा व्यक्त सपनाको सन्दर्भ विश्लेषण गर्दा बालबालिका आफूले चाहेका, कल्पना गरेका तथा भोगोका विषय वा वस्तुलाई सपनामा देखेका सन्दर्भलाई समावेश गरिएको निष्कर्ष प्रस्तुत अध्ययनवाट प्राप्त भएको छ।

शब्दकुन्जी : बालसाहित्य, बालउपन्यास, बालमनोविज्ञान, सपना, इच्छापूर्ति

\section{विषयपरिचय}

मानिस निदाएको बेलामा उसको मानसिकतामा सिर्जना हुने र व्यक्तिले अर्धचेतन या अवचेनले अनुभूति गर्ने काल्पनिक, स्वाभाविक, अस्वाभाविक घटना, विषय, परिस्थिति नै सपना हुन् । सपनामा अचेतन मानसिक प्रक्रिया स्वतन्त्र किसिमले मानव मस्तिष्कमा विचरण गई्छ् । व्यक्तिका अचेतनमा लुकेका इच्छाहरू सपनाका माध्यमबाट बाहिर निस्कने मौका पाउँछन्। सामाजिक संरचना र बुद्धिका कारण व्यक्तिका चेतन मनले थिचेका इच्छाहरूको प्रकटीकरण नै सपना हो। सपनामा हाम्रो अतृप्त अचेतन मनका इच्छाहरू सन्तुष्ट हुन्छन् अर्थात् सपनाको सम्बन्ध अचेतन मनसँग हुन्छ (भण्डारी, २०४६, पृ. १०३) 
इच्छापूर्ति, दुश्चिन्ता, प्रतिरोध, दण्डात्मक, भविष्य, गति, पुनरावर्तक आदि विविध प्रकृति तथा प्रकारका सपना हुने (भण्डारी, २०४६, पृ. १०४) जनाइएको छ। नैतिक मूल्य, सामाजिक संरचना एवम् निर्मित आदर्शका कारणले भौतिक तथा सामाजिक दुनियाँको अगाडि व्यक्त गर्न नसकिएका अनैतिक चाहनाहरू, छाडा क्रियाकलापहरू, अरुचिकर तथा अप्रिय विचारहरू एवम् चाहनाहरूले सपनामा स्वतन्त्रतापूर्वक प्रकट हुने मौका प्राप्त गर्छन्। सपनाका माध्यमबाट मानिसको मनले चाहेका तर प्राप्त गर्न नसकेका वस्तु, विषय आदिमा पहुँच पुरयाउँछ। सपनामा हाम्रो अतृप्त अचेतन मनका इच्छाहरू सन्तुष्ट हुन्छन् अर्थात् सपनाको सम्बन्ध अचेतन मनसँग हुन्छ। इच्छापूर्ति, दुश्चिन्ता, प्रतिरोध, दण्डात्मक, भविष्य, गति, पुनरावर्तक आदि विविध प्रकृति तथा प्रकारका सपना सिर्जना हुन्छन् । व्यक्तिको मानसिकतामा रहेका अव्यक्त चाहनाको उद्घाटन मानिने मनोविज्ञानको अत्यन्त महत्त्वपूर्ण र सघन पक्ष सपना भएकाले नेपाली बालउपन्यासमा प्रस्तुत बालपात्रहरूले देखेका सपनाहरूको उल्लेख गरी विश्लेषण गरिएको छ।

\section{अध्ययन विधि र प्रक्रिया}

प्रस्तुत अनुसन्धानात्मक लेख गुणात्मक ढाँचाको अनुसन्धान हो । यस लेखमा पुस्तकालयीय अध्ययन प्रक्रियाबाट तथ्य सङ्कलन गरिएको छ भने प्रस्तुतिमा वर्णनात्मक विधिको उपयोग गरिएको छ। नेपाली बालउपन्यासमध्ये सपनाको विषयवस्तु प्रस्तुत गरिएकालाई अध्ययनमा समावेश गरिएको छ। यस अध्ययनमा उपन्यास छनोटको आधार बालउपन्यासमा प्रस्तुत सपनाको सन्दर्भ हो । सपनाको सन्दर्भ प्रस्तुत भएका कविताराम श्रेष्ठको मावलीको यात्रा, शर्मिला खड्काको सानी, नवराज रिजालको रोजीको हवाइजहाज, अनन्त वाग्लेको यार्चा, अनुराधाको मेरो कथाको एलियन, नेत्र तामाङ बोजराज र बाउन्ने, कृष्णदीप सिनदेलको चोरी भो जुत्ता, उज्वलविक्रम खड्काको पिन्टो, राजकुमारी र भुँडे यती, कपिलमणि ज्ञवालीको कालो पाटी तथा ललिता दोषीको नीलकमल बालउपन्यासलाई प्राथमिक सामग्री तथा सम्बन्धित सैद्धान्तिक ग्रन्थलाई द्वितीयक सामग्रीका रूपमा उपयोग गरी प्रस्तुत लेख तयार गरिएको छ। विभिन्न सैद्धान्तिक ग्रन्थहरूको अध्ययन गरी बालमनोविज्ञानअन्तर्गत पर्ने सपनाको सैद्धान्तिक स्वरूप निरूपण गरिएको छ। त्यसपश्चात् सपना र बालमनोविज्ञानको अन्तरसम्बन्ध स्थापित गर्दे नेपाली बालउपन्यासमा प्रयोग गरिएका उपर्युक्त उपन्यासमा रहेको सपनाको सन्दर्भ एवम् विषयवस्तु खोजी गरी तिनको तथ्यपरक विश्लेषण गरिएको छ।

\section{बालसाहित्य र बालउपन्यास}

बालसाहित्यलाई अर्थ्याउने ऋमममा नेवृश २०७५ ले बालकले पढ़न सक्ने साहित्य र बालहितकारी साहित्य भनी अर्थ्याएको छ। प्रौढहरूद्वारा बालबालिकाका लागि लेखिएको साहित्यलाई बालसाहित्य भनिन्छ भने बालबालिकाद्वारा लेखिएको साहित्यिक रचनालाई पनि बालसाहित्य भनिन्छ (पराजुली, २०६६, पृ. १६)। बालबालिकाहरूलाई मनोरख्जन दिने रचनात्मक एवम् सिर्जनात्मक हुन प्रेरणा दिने र ज्ञानविज्ञाका विषय सम्बन्धमा जानकारी दिने विषयवस्तुलाई उनीहरूको उमेर अनुसारको सरल सरस भाषामा रोचक तवरले लेखी रड्गीन चित्रहरूसमेत सकेसम्म समाविष्ट गरी कलात्मक तरिकाले प्रकाशन गरिएको कृति नै बालसाहित्य हो (प्रधान, २०६९, पृ.३०)। बालबालिकाका निम्ति रचिएको साहित्य; बालसाहित्यमा तीन विशेषता हुन्छन् : (१) बालपात्रको प्रयोग वा बालबालिकाले पहिचान गर्न सक्ने पात्र समाविष्ट, (२) बालबालिकाकै लागि भनेर प्रक्षेपित सारवस्तु वा चेतनामूलक प्रयोजन र (३) बालबालिकाका निम्ति उपयुक्त हुने शब्द र वाक्यसंरचनायुक्त भाषाको प्रयोग । बालसाहित्य बालबालिकाको उमेरगत अभिरुचि, 
नेपाली बालउपन्यासमा प्रस्तुत सपनाको विश्लेषण/ 135

मानसिकता र सकारात्मक कल्पनालाई स्थान दिने मनोरज्जनात्मक सिर्जना हुनाले यो उनीहरूको पहुँचभित्र रहनु आवश्यक छ (एटम, २०७४, पृ. १७०)। बालसाहित्य भन्नेबित्तिकै बालबालिकाका लागि सिर्जना गरिएको साहित्य भन्ने बुक्किन्छ (कसजू, २०७४, पृ. २५२)। लोक बालसाहित्य (बाल लोकगीत, बाल लोककथा आदि) को पृष्ठभूमिमा बालबालिका स्वयम्ले वा अन्य उमेरका सर्जकहरूले सिर्जना गरेका र बालबालिकाले त्यसमा स्वत्वबोध गर्दे त्यसको गायन, पठन, अवलोकनबाट आनन्द प्राप्त गर्ने खालका रचनाहरू नै बालसाहित्यिक सिर्जनाहरू हुन् (घिमिरे, २०७४, पृपृ. १३ - १४)। यी विविध मान्यताका आधारमा बालसाहित्य बालबालिकाका लागि मूलतः मनोरज्जन दिने उद्देश्यले सिर्जना गरिन्छन् र अंशतः सन्देश प्रवाहको पनि उद्देश्य रहन्छ भन्न सकिन्छ।

बालउपन्यासका माध्यमबाट बालबालिकालाई मनोरज्जन प्रदान गर्न सकिन्छ। मनोविज्ञानको उद्घाटनसहित अभिप्रेरणा पानि सिर्जना गर्न सकिन्छ। यति मात्र होइन सामाजिक सहभाव, ज्ञानको विकास तथा सदाचारी आचरण निर्माणमा पनि बालउपन्यासको उच्च महत्ता रहन्छ। बालउपन्यासको सान्दर्भिकताका सम्बन्धमा प्रधान (२०६९) भन्छन् : बालउपन्यासका माध्यमबाट हामी बालबालिकाहरूलाई विभिन्न विषयको ज्ञान दिन सक्छौं - इतिहास, विज्ञान, भूगोल आदि विषयगत ज्ञानलाई उपन्यासका माध्यमबाट प्रस्तुत गर्दा रोचक हुने हुनाले बालबालिकाहरू पढ्न रुचाउँछन् भने उनीहरूले छिटै बुक्छन् पनि । यसतर्फ बालउपन्यास लेखकले ध्यान दिनु उपयुक्त हुन्छ। वालउपन्यासलाई विषयवस्तुका आधारमा यसरी वर्गीकरण गर्न सकिन्छ १. सामाजिक, २. ऐतिहासिक, ३. भौगोलिक, ४. वैज्ञानिक, ४. साहसिक, ६. रहस्य र ७. अन्य (पृ. १२७)। यसरी बालउपन्यासमा विविध विषयवस्तुले स्थान पाएका हुन्छन् भन्न सकिन्छ।

नेपाली बालउपन्यासको परम्परा अत्यन्त छोटो रहेको अध्येताहरूले उल्लेख गरेका छन् । नेपाली बालउपन्यासको प्रारम्भ २०१५ सालदेखि मात्र भएको जनाउँदै (प्रधान, २०६९, पृ. १२७) नेपाली बालउपन्यासको सड्ख्या २०० को हाराहारीमा रहेको उल्लेख गरिएको छ। नेपाली बालउपन्यासको मौलिक कृति त अक २०२२ सालमा प्रकाशित साबु हो (प्रधान, २०६९, प्. १२७)। हुन त १६३३ सालमा लेखिएको हितोपदेश मित्रलाभलाई नै बालआख्यानको पहिलो कृति मान्नुपर्ने (घिमिरे, २०७४, पृ. १३९) धारणा पनि रहेको छ। बालउपन्यासमा बालसाहित्यका अन्य विधामा जस्तै बालमैत्री पात्र, भाषा, शैली तथा विषय नै प्रविष्ट हुन्छ र हुनुपछ। अक कतिपय रचनाहरू बालआख्यानका रूपमा मात्र देखिएका छन्। त्यस्ता रचना न त कथाका रूपमा देखिन्छन् न त उपन्यासकै दर्जामा। यस्ता सामग्रीलाई अध्यायपुस्तकका रूपमा चित्रण गरिएको (घिमिरे, २०७४, पृ. १३९) पनि पाइन्छ। तसर्थ बालउपन्यासमा लामो शृड्खला नभएको स्पष्ट हुन्छ।

\section{बालमनोविज्ञान}

मनोविज्ञान व्यक्तिका मानसिकता, संवेग तथा व्यवहारको अध्ययन गर्ने शास्त्र हो। व्यक्तिको मानसिकता वा मानसिक संरचनाका आधारमा उसले गर्ने समग्र व्यवहारको अध्ययन मनोविज्ञानमा हुन्छ। मनोविज्ञानका सवालमा रेगमी (२०६४) भन्छन् :

व्यक्तित्व मनोविज्ञानले पूर्ण व्यक्तिको समग्र अध्ययन गई र उसको विषयमा निर्णय गर्न सक्छ। यसो विचार गर्दा यो व्यक्तिका लागि दर्शन हो। धेरैजसो व्यक्तित्व सिद्धान्तहरूले 
निम्नलिखित चार तत्त्वहरूलाई अँगालेका हुन्छन् - (१) व्यवहारलाई सन्चालन गर्ने प्रेरक वा प्रचालक शक्तिहरू, (२) मानसिक संरचना र मनका घटकहरू जसबाट वातावरणको व्याख्या गरिन्छ र व्यवहारलाई सल्लाह दिनका लागि निर्णय लिइन्छ, (३) ती मार्गहरू जसमा व्यक्तिहरू एकअर्काभन्दा फरक हुन सक्छन, या त प्रेरणाको शक्ति वा स्रोतका रूपमा अथवा मानसिक संरचनाहरूका रूपमा र (४) जन्मदेखि जीवनपर्यन्त विकसित भइरहने ती भिन्नताहरूलाई समाविष्ट गर्न सकिन्छ। (पृ. ०१)

मनोविज्ञान मन र व्यवहारको विज्ञान हो। मनोविज्ञानमा चेतन र अचेतन मनका साथै व्यक्तिका भावनाहरू र सोचाइसमेत समावेश हुन्छन् । यो विशाल क्षेत्र भएको विधा हो जहाँ प्राकृतिक र सामाजिकविज्ञानले अध्ययन गर्न नसकेका पक्षहरूको अध्ययन गई। मनोविज्ञानले व्यक्तिका मानसिकतासँग सम्बद्ध व्यवहारको अध्ययन त गई नै यसका साथै व्यक्तिगत, सामाजिक तथा संज्ञानात्मक पक्षको पनि अध्ययन गई। व्यक्तिगत र सामाजिक व्यवहारमा मानसिक कार्यहरूको भूमिका विश्लेषणका लागि र शारीरिक तथा जैविक प्रक्रियाहरूको अन्वेषण गर्नका लागि पनि मनोविज्ञान नै उपयोग हुन्छ। त्यस्तै व्यक्तिगत अनुभूति, ध्यान, भावना, बुद्धि, प्रेरणा, मस्तिष्कको काम, र व्यक्तित्त्वको अध्ययन तथा व्यक्तिगत मनोविकारको विश्लेषणमा पनि मनोविज्ञानकै उपयोग हुन्छ। व्यक्तिगत तथा सामाजिक पारस्परिक सम्बन्ध, मनोवैज्ञानिक लचकता, पारिवारिक सहसम्बन्धको अध्ययन पनि कुनै न किसिमले मनोविज्ञानसंग सम्बन्धित हुन्छ। तसर्थ मनोविज्ञानको अध्ययन क्षेत्र अत्यन्त विशद छ।

बालमनोविज्ञान मनोविज्ञानको महत्त्वपूर्ण क्षेत्र हो । यसलाई विकासात्मक मनोविज्ञान पनि भनिन्छ। अर्को शब्दमा बालविकास भनेर पनि अर्थ्याइन्छ। बालविकासमा जैविक, मनोवैज्ञानिक र भावनात्मक परिवर्तनहरू पर्छन्। मानिसको जन्मदेखि र किशोरावस्थाको समयसम्ममा विकास हुने व्यक्तिगत संवेग, शारीरिक परिर्वतन, सांस्कृतिक तथा समाजिक चेत, खुसी, बेखुसी, सङ्कट, विकासका चरणगत वैशिष्ट्य आदि पक्ष बालमनोविज्ञानका क्षेत्र हुन् भन्न सकिन्छ।

\section{सपना}

सपना मानिसका अर्धचेतन र अवचेतनमा रहेका मनोभावना, मनोद्वेग आदि भावना तथा मानिसका कल्पना, पीडा, अभाव तथा चाहनाको प्रकटन हो भनिन्छ। मानिस निद्रामा पुगेपछि उसका अचेतन मनका भावहरू स्वतन्त्र हुन्छन् । विपनामा विविध कारणबाट सचेत मनले दबाएर राखेका भावना वा अव्यक्त मनोकाड्क्षा सपनामा प्रकट हुन्छन् (टाइसन, २०१०, पृ.१६)। सपनालाई मानिसका मनमा रहेका विचार तथा भावनाको उद्घाटन मानिन्छ।

सपनालाई मानवीय इच्छा, संवेदना, भावना, विचारहरूको प्रकटनका रूपमा व्याख्या गर्न सकिन्छ जुन निद्राको निश्चित चरणहरूमा व्यक्तिको दिमागमा अनैच्छिक रूपमा देखा पर्दछ। हुन त वास्तवमा सपनाको उद्देश्य र सामग्रीका बारेमा तथ्यपरक प्रामाणिक निष्कर्ष प्राप्त गर्न नसकिए तापनि तिनीहरू निश्चित रूपमा धार्मिक र दार्शनिक चासोको विषय र रेकर्ड गरिएको इतिहासभरि वैज्ञानिक अनुमानको विषयचाहिँ भएका छन्। सपनाका आयामका बारेमा होरिकावा र साथीहरू (२०१३) ले मानिसका सपनाहरूको आयाम या लम्बाइमा हुने जनाएका छन् । कुनै सपना केही सेकेन्डका मात्र हुने र बिस बिस मिनेटको अन्तरालमा 
नेपाली बालउपन्यासमा प्रस्तुत सपनाको विश्लेषण/ 137

आइरहने र कुनै सपना निकै लामा प्रकृतिका र शृड्खलाबद्ध हुने पनि जनाएका छन्। औसतमा मानिसहरूले हरेक रात तीनदेखि पाँचओटा सपना देख्ने, कसै-कसैले सातवटासम्म पनि सपना देख्ने जनाएका छन्। मानिसले देख्ने अधिकांश सपना सचेत अवस्थामा आइपुगदा विस्मरणमा पुगिसकेका हुने र केही सपना मात्र स्मरण गर्न सकिने पनि उल्लेख गरेका छन् ।

सपनाका बारेमा बराल (२०६६) ले फ्रायडको सन्दर्भ दिंदै भन्छन् :

अचेतन मानसिक प्रक्रियालाई बिनाप्रतिबन्धन देखाउने कार्य सपनाले गई। ... निदाएको बेला चेतनको रक्षक कमजोर हुने भएकाले अचेतनमा लुकेका इच्छाहरूले बाहिर निस्कने मौका पाउँछन्। चेतनले थिचेका त्यस्ता दमित इच्छाहरूको प्रकटीकरण सपनामा हुन्छ। भौतिक तथा सामाजिक दुनियाँको अगाडि अभिव्यक्त गर्न नसकिने अनैतिक चाहनाहरू, छाडा क्रियाकलापहरू, अरुचिकर तथा अप्रिय विचारहरू अचेतनमा दबिएर रहेका हुन्छन् र यस्ता चाहनाहरूले सपनामा खुलेआम बाहिर प्रकट हुने मौका पाउँछन् । (पृप्. ४० - ४१)

स्क्रेड्ल (२००७) ले सपनाको ऐतिहासिकताका सन्दर्भमा भन्छन्,

सन् $9 ९ 00$ को प्रारम्भमा, सिग्मन्ड फ्रायडले सपनाको सिद्धान्त र तिनीहरूको व्याख्याको बारेमा व्यापक रूपमा आफ्ना धारणाहरू प्रस्तुत गरेका थिए । फ्रायडले सपनालाई मानिसका चिन्ता र इच्छाहरूको अभिव्यक्तिका रूपमा व्याख्या गरेका थिए। मानिसका प्राय: बाल्यकालमा दबिएका चाहना तथा सम्कनाहरू सपनाका रूपमा प्रकट हुन्छन् भन्ने मान्यता राख्ने फ्रायडले प्रत्येक सपनाका विषय कुनै न कुनै किसिमले यौनसँग सम्बद्ध हुन्छ भन्थे। साथै उनले सपनाका माध्यमबाट अप्राप्य चाहना एवम् यौनिक इच्छाको परिपूर्ति पनि हुन्छ भन्ने धारणा राखेका थिए । उनले सपना पूर्णतः मनौैैज्ञानिक विषय भएको पनि जनाएका थिए। हुन त सपनाका सन्दर्भमा आजभन्दा करिब पाँच हजार वर्षपहिले नै मेसोपोटामियामा उल्लेख भएको जनाइएको छ। त्यहाँका माटोको ढिस्काहरूमा रचित दस्तावेजबाट सपनाका विषयसम्बन्धी सूचनाहरू अनुसन्धानबाट प्राप्त भएको उल्लेख छ। रोमन र ग्रिक समयमा सपनाहरू मृतक मानिसहरूबाट पठाइएका सन्देशहरू हुन्, र तिनीहरू भविष्यका भविष्यवाणीहरू हुन् भनी त्यहाँका मानिसहरूले विश्वास गर्थे । फलस्वरूप त्यसपछि त्यहाँ केही मानिसरूले सपनालाई भविष्यवाणी गर्ने आधार मानेर पेसा चलाए र संस्कृतिक रूपमा पनि विकास गरे ।

यस सन्दर्भबाट पुष्टि हुन्छ कि सपनाका बारेमा निकै पहिलेदेखि नै चर्चा भएको पाइए तापनि फ्रायडको आगमनपश्चात् सपनाका बारेमा तथ्यपरक र वैज्ञानिक दृष्टिले व्याख्या गर्दै मनोविज्ञानसंग सम्बद्ध गर्ने कार्य भएको देखिन्छ। त्यसो त निद्रा र सपनासम्बन्धी अनुसन्धानकर्ता रोजालिन्ड कार्टराइटले सपनाहरूमा जीवनका घटनाहरू प्रतिबिम्बित हुने जनाएका छन् । यसले सपना अतृप्त र अप्राप्य चाहनाको प्रतिबिम्बन मात्र होइन यो त अनुभवको उद्घाटन पनि हो भन्ने स्पष्ट हुन्छ। गेनारो र अन्य (२०१९) ले रोमाज्चक, डरलागदा, उदास, जादुगरी, साहसी र यौनजन्य आदि सपनाका विभिन्न प्रकृति उल्लेख गरेका छन् । मानिसका सपनाहरू सामान्यदेखि लिएर विचित्र र पूर्णतया काल्पनिक एवम् विश्वासै नलाग्ने पनि हुन्छन्। 
यस्ता अत्यन्त काल्पनिक एवम् असम्भ विषयवस्तु सपनामा आउनुले सपना अव्यक्त र अप्राप्य विषयमा मात्र सीमित छ भन्न सकिंदैन। केही सपना स्वाभाविक एवम् स्पष्ट हुन्छन् तर अधिकांश सपना सपना देख्ने व्यक्तिको नियन्त्रणबाहिर रहेका हुन्छन्। जाङ र गौ (२०१६) ले कतिपय अवस्थामा सपना सचेत हुन्छन् र कहिलेकाहीं रचनात्मक विचार प्रत्यारोपणसमेत गर्ने हुनाले सपनालाई प्रेरणाका रूपमा पनि लिन सकिन्छ भन्ने विचार राखेका छन्।

सपनाका माध्यमबाट मानिसको मनले चाहेका तर प्राप्त गर्न नसकेका वस्तु, विषय आदिमा पहुँच पुर्याउँछ। सबै सपनामा अवचेतन मनमा रहेका कुनै कुनै किसिमका भावनाहरूको प्रकटन भएको हुन्छ। तसर्थ सपना व्यक्तिको मानसिकतामा रहेका अव्यक्त चाहनाको प्रतिरूप हो भन्न सकिन्छ। यहाँ नेपाली बालउपन्यासमा प्रस्तुत बालपात्रहरूले देखेका सपनाहरूलाई विश्लेषण गरिएको छ।

\section{नेपाली बालउपन्यासमा प्रस्तुत सपना}

कविताराम श्रेष्ठको मावलीको यात्रा (२०५९) बालमनोवैज्ञानिक उपन्यास हो। सबै मानिसले सपना देख्छन्। बालबालिकाले पनि सपना देखिरहेकै हुन्छन् । सपना देख्नु मनोवैज्ञानिक कार्य हो। मनोवैज्ञानिकहरूले सपनालाई अवचेतन मनको उपज ठान्छन्। चेतन मनले सोचेका, अनुभव गरेका, कल्पना गरेका, प्राप्त गर्न नसकेका विभिन्न सूचना, घटना तथा कार्यहरू सपनामा देखिन्छन् भन्ने मनोवैज्ञानिकहरूको विश्वास छ। मनोविज्ञानले त विपनामा प्राप्त गर्न नसकेका विषय या वस्तु सपनामा देखेर मानिस तुष्ट हुन्छ भन्ने मान्यता राख्छ। उपन्यासकार श्रेष्ठले पनि बालपात्र मुनाका माध्यमबाट सपनाका बारेमा भन्छन् :

मान्छे सुते पनि उसको चेतना सुतेको हुँदैन। त्यसै बेला त्यस व्यक्तिको अवचेतन मनमा भएका कुराहरू ऊ सपनामा देख्छ। (श्रेष्ठ, २०प९, पृ. ६३)

उक्त उपन्यासको बालपात्र ईशानले पनि सपना देखेको छ। दिनभरको थकाइ, डर तथा चिन्ता नै उसको सपनामा देखिएको छ। ईशानको दिनभर मनमा उत्पन्न भएका र भोगेका घटनाको प्रतिविम्बन उसको सपनामा भएको छ। यसबाट सपनाले व्यक्तिको मानसिकता वा मनोवैज्ञानिक पक्षको उद्घाटन गछ भन्ने यहाँ पुष्टि हुन्छ :

सपनामा हामी यहाँ सुतेका रहेछौं। मेरा सबै अड्गहरू बेस्सरी दुखिरहेका थिए। मैले दुखेका ठाउँहरू तपाईंलाई देखाएँ। तपाईंले दुखिरहेका ठाउँहरूमा हेर्दा त्यहाँ फलामका किलाहरू गढेको पाउनुभएछ। मैले पनि देखें मेरा सबै दुखेका ठाउँहरूमा फलामका तिखा तिखा काँटीहरू गाडिएका थिए। म अति नै डराएँ। प्रत्येक किलामा धागाहरू पनि गाँसिएका रहेछन्। ती धागाहरू खोलापारिसम्म तन्किएका थिए। तिनका छेउहरू पारि राँको बालेर उभिएका पाँचओटा डरलागदा भूतहरूका हातमा थिए। उनीहरूले ती धागोबाट मेरो रगत तनतनी चुस्ता रहेछ् । जति चुस्यो मलाई उति दुख्दो रहेछ। त्यसपछि, तपाईंले मेरा शरीरबाट सबै किलाहरू उखेल्नुभयो। तिनका धागाहरू पनि चुँडालिदिनुभयो। मलाई दुख्न निको भयो। तर राँके भूतहरूले त्यसै छोड्ने भएनन् । उनीहरू सबै रिसाउँदै खोलाबाट 
नेपाली बालउपन्यासमा प्रस्तुत सपनाको विश्लेषण/ 139

वारि आए। खोलामा उनीहरूले खुट्टा चोपल्नै परेन । हावामा नै उनीहरू सरर आए। म आत्तिएँ। तर तपाईंचाहिं डराउनुभएन। (श्रेष्ठ, २०४९, पृपृ. ६६-६९)

उल्लेख गरिएको ईशानको सपनाको सन्दर्भमा उसले सुत्नुअगाडि भोगेका घटना र मनमा उब्जेको भूतसम्बन्धी जिज्ञासामा आधारित छ। बाटामा भेटिएको खोला, रातमा राँको बालेका मानिसको सन्दर्भ र भूतको कुरा, दिदीको आत्मविश्वसास र सहयोग, आफ्नो दुख यी सबै उसले भोगेका र सोचेका विषयवस्तुमा केन्द्रित छन्। यसबाट पनि प्रस्ट हुन्छ कि सुत्तुआगडि मानिसले जे जस्ता अनुभव भोग्छ वा सोच्छ तिनले उसको मस्तिष्कमा प्रभाव पारेका हुन्छन् र सपनामा प्रकट हुन्छन्। यसरी उपन्यासकारले बालमनोविज्ञानको प्रमुख पक्ष सपनालाई उपन्यासमा प्रभावकारी तवरले प्रविष्ट गरेका छन् ।

शर्मिला खड्काको उपन्यास सानी (२०६०) कारुणिक विषयबाट कथा प्रारम्भ भएको बालउपन्यास हो । उपन्यासकी पात्र सानी सानैमा आफ्नी आमा परलोक भएपछि सानी आमाबिनाकी भएकी थिइन्। उनकी हजुरआमाले उनलाई उनकी मम्मी आकासमा भएको जनाउँथिन्। सानी पनि त्यही विश्वासमा थिइन्। आफ्नी मम्मीलाई चिठी लेख्दै आकासमा पुरयाइदिन आग्रह गर्दै हावामा उडाउने (पृ.३), मम्मीको अभावमा दुखी हुनुपरेको र साथीहरूले पनि हेला गर्ने गरेको सन्दर्भ (पृ.६), साथीको जन्मोत्सवमा आफ्नी मम्मी भएको भए धेरै रमाइलो र आनन्द हुन्थ्यो भन्ने कल्पना गर्नु (पृ.९) आदि सन्दर्भले सानीको मनमा पीडा दिइरहेको अवस्था बुक्न सकिन्छ। यस्तो विवशता भोग्न बाध्य बनेका बालबालिकाहरूमा मनोवैज्ञानिक सड्कट, डर, चिन्ता, पीडाको आधिक्य रहन्छ। भलै यस उपन्यासको कथानकले सकारात्मक दिशा (पृपृ. २०-२१) लिएको छ। आमाको अभावमा बालबालिकाहरू विच्छिप्त बन्दछन् र उनका पीडा एवम् चाहनाहरू सपनामा प्रकट हुन्छन् ।

उनी सपनाको संसारमा डुल्न थालिन्। उनले सपनामा आफ्नी मम्मी परी भएर आएको देखिन् । उनलाई परी मम्मीले बोकेर धैरै टाढाटाढा घुमाउन लगिन् । सानी पनि खुसी हुँदै परी मम्मीसँग गइन् । उनी राम्रा राम्रा बगैंचामा मिठा मिठा फलफूल फलेका रुखहरू भएठाउँ पुगिन् । ... उनले सानीलाई सुस्मिताको जन्मदिन पार्टीमा भएजस्तै खेलौनाहरू ल्याइदिइन् । उनले सानीलाई मिठा मिठा खानेकुरा खान दिइन् । (खड्का, २०६०, पृ. १०)

उदाहरणमा सानीले आफ्नो अभाव पूर्ति गरेकी छन्। उनले आमालाई सपना देखेकी छन्। यस उपन्यासमा आफ्नी मम्मीको अभावमा सौतेनी आमाको व्यवहारबाट नभई साथीहरू र तिनका आमाहरूको व्यवहारबाट, जो आम समाजको प्रतिविम्बन पनि हो, सानीमा बढी पीडा तथा चिन्ता पैदा भएको जनाइएको छ।

नवराज रिजालको बालउपन्यास रोजीको हवाइजहाज (२०६७) मा बालबालिकाहरू विपनामा प्राप्त गर्न नसकेका खुसी तथा आनन्द सपनामा देख्छन् र आनन्दित हुन्छन् भन्ने देखाइएको छ। त्यसो त विपनामा भोगेका, सोचेका तथा प्राप्त गरेका सन्दर्भ, विषय, वस्तु तथा घटना पनि सपनामा नदेखिने होइनन् । तसर्थ सपनाका बारेमा स्पष्ट, प्रामाणिक तथा विश्वनीय तथ्यहरूको रिक्तता कायमै छ। हुन त सपनालाई सन्तुष्टिको माध्यम मान्ने विद्वान् पनि छन् । जेहोस, सपना एउटा विशाल अनुभूति हो जसको पूर्वकल्पना वा अनुमान गर्न सकिदैन । 
‘तिनीहरूभन्दा म के कम। ल हेर मेरा खेलौना गन त कतिओटा छन्। आमाले किन्न नसकेर के भो त ? फुपूले ल्याइदिनुभएन ? उहाँ कति जाती हुनुहुन्छ। मेरो मनको कुरा बुक्केर ल्याउनुभएको। तिमीहरूको भन्दा मेरो राम्रो । यस्तो त कहिल्य देखेका छैनौ। हुन त मैले पानि देखेको छैन । त्यतिबेला मलाई कम हेपेका थियौ ? उर्मिला र चम्पाले नसम्काएको भए कम रुन्थें होला ? अब हेरौं न नानीहरूको ताई' ऊ एक्लै खुतुतु हाँसी। (रिजाल, २०६७, पृ. १४)

माथिको उदाहरणमा उपन्यासकारले उक्त उपन्यासमा अभाव तथा सड्घर्षमा जीवन सक्रिय तुल्याएकी बालपात्र रोजीले आफ्ना साथीहरूसँग धेरै खेलौनाहरू रहेका तर आफूसँग नभएकाले दुखी हुन्छिन् । आफूसँग खेलौना नभएका साथीहरूले समेत बेवास्ता गरेको अवस्थामा फुपूले खेलौना ल्याइदिएपछि निकै खुसी भएकी थिइन्। साथीहरूको व्यवहारबाट निराश बनेकी रोजीले सपनामै साथीहरूको बिचमा पुगेको, साथीहरूलाई आफ्ना खेलानाहरू सगर्व देखाएको र खुसी भएको अवस्था उद्घाटन गरिएको छ।

अनन्त वाग्लेको यार्चा (२०७२) नेपालको प्राकृतिक सम्पदा तथा जडिबुटीलाई केन्द्र बनाइएको उपन्यासका हो। यार्चा नेपालको सम्पत्ति भएको र त्यसको अन्तर्सम्बन्ध वातावरणीय पक्ष तथा आर्थिक एवम् समाजिक पक्षसँग पनि अभेद्य रहेको विषय स्रष्टाले मोतीका माध्यमबाट उल्लेख गरेका छन् ।

मैले त यार्चासँग भेटिसकें। कुराकानी पनि गरें। यार्चा त क्या मज्जाले मसंग दोहोरो संवाद पनि गरिरहेको । (वाग्ले, २०७२, पृ. ५००)

मोतीले सपनामा यार्चासँग संवाद गरेको सन्दर्भले यार्चाको वास्तविकता उद्घाटन भएको छ। सपनाका माध्यमबाट यार्चाको वास्तविकता उद्घाटन भएको माथिको उदाहरणमा बालपात्र मोतीको काल्पनिकता र चाहना प्रस्तुत भएको छ।

अनुराधाको मेरो कथाको एलियन (२०७३) पूर्णतः विज्ञानमा आधारित तर काल्पनिक प्रस्तुति रहेको उपन्यास हो। बालबालिकाहरू आफूले सुनेका, देखेका तथा कल्पना गरेका विभिन्न विषयवस्तुमा आधारित सपना देख्छन्। यस कृतिमा एलियनका बारेमा उल्लेख गरिएको छ। पृथ्वीबाहेकको ग्रहका बारेमा उल्लेख गरिएको छ।

आँखा खुल्दा त म आफ्नै बिस्तारमा थिएँ। म कसरी घर पुगें ? अल्बाटोस, टिड्गोरा, दीपा र पिड्की कहाँ गए त ? त्यो सबै सपना थियो ? म छिटोछिटो तयार भई स्कुल गएँ । कक्षामा पुगदा त सधैंकैं दीपा साथीहरूसँग थिइन् । उनी गुलाबी रङका कुराहरू देखाउनमै व्यस्त थिइन् । उनले मतिर हेर्दा पनि हेरिनन् । कक्षामा मिस आउनुभयो । (अनुराधा, २०७३, पॄ. ६२)

माथिको उदाहरणमा काल्पनिक सन्दर्भ छ। त्यसो त समग्र उपन्यास नै काल्पनिक कृति हो। बालबालिकाले यस्ता प्रकृतिका कल्पना गईन्, सपना देख्छन् र आनन्दित हुन्छन् । म पात्रले दीपालगायत सबै साथीलाई सपना पनि देख्छ, विपनामा छलफल भएजस्तै गुलाबी रङको प्रसड़ग पनि देख्छ। यसबाट सपनाका 
नेपाली बालउपन्यासमा प्रस्तुत सपनाको विश्लेषण/ 141

लागि विपनाका घटना र वस्तुको साथ चाहिन्छ भन्ने पनि प्रस्ट हुन्छ। यति मात्र होइन बादल के हो ? असिना कसरी बन्छ ? पानी कसरी पछ, इन्द्रेणी किन, कसरी र कस्तो देखिन्छ ? गुलावी रङ के हो ? आदि विषयवस्तुका बारेमा उल्लेख गरिएकाले रोचक छ र विज्ञानलाई पनि प्रस्तुत गरिएकाले सार्थक पनि छ।

नेत्र तामाङ बोजराज र बाउन्ने (२०७३) मा काल्पनिक विषयवस्तुलाई समाजको यथार्थसँग नजिक राख्दै भुइँचालोले नेपाली समाज तथा बालबालिकाहरूमा पारेको मनोवैज्ञानिक प्रभावलाई उक्त रचनामा व्यक्त गरिएको छ। प्राकृतिक विपत्तिले पारिवारिक बिछोड निम्त्याएको अवस्थामा बालबालिकाहरूमा मानसिक समस्या पनि देखिन सक्छ भन्ने विषयवस्तु उठान गर्दै स्रष्टाले त्यस्ता सङ्कटको समाधानका लागि मनोपरामर्शको आवश्यकता रहेको जनाएका छन् ।

स्मृतिले राति सपना देखिन्। सपनामा उनी बोजराजको उपचार गराउन भनी सहरमा पुगेकी थिइन् । तर अस्पताल नभेटेर छट्पटिंदै गर्दा उनको निद्रा खल्यो। (तामाङ, २०७३, पृ. ४३)

माथिको उदाहरणमा कृतिको मुख्य बालपात्र बोजराज आफ्नी आमाको मृत्युपश्चात मानसिक विचलनको अवस्थासम्म पुगेको छ। उसकी साथी स्मृतिले त्यस्तो अवस्थामा पुगेको साथीलाई उपचार गराउन पाए हुत्थ्यो भन्ने कल्पना गरेकी छन्। बालबालिकाहरू सामान्यतया आफ्ना चाहनालाई अवचेतन मनमा खेलाइरहेका हुन्छन् भन्ने कुरा यहाँ पनि स्मृतिले सपनामा देखेको घटनाले प्रस्ट पारेको छ।

कृष्णदीप सिग्देलको चोरी भो जुत्ता (२०७३) उपन्यासमा बालपात्र रामबाबुलाई गलत आचरण भएको पात्रका रूपमा देखाइएको छ भने रामबहादुर इमानदार र अनुशासित देखाइएको छ।

रामबहादुरका जुत्ता साँच्चै नै लोभलागदा थिए। रामबाबुलाई छट्पट् भइरह्यो। के निद्रा आओस् । कसो कसो आँखा कपक्क हुँदा पनि सपनामा त्यही जुत्ताले जिस्काइरह्या । (सिनदेल, २०७३, पृ. २९)

माथिको उदाहरणमा उपन्यासको बालपात्र रामबहादुरले नयाँ जुत्ता लगाएर आएपछि, अर्को पात्र रामबाबु पनि ती नयाँ जुत्ता लगाउन पाए हुत्थ्यो भन्ने सोचाइमा पुगेको छ। आफ्नो बाबुलाई त्यस्तै नयाँ जुत्ता किनिदिन आग्रह पनि गरेको छ, तर बाबुले नकिनिदिने जनाएपछि उसले सपनामा तिनै नयाँ जुत्ता देखेको छ।

उज्वलविक्रम खड्काको पिन्टो, राजकुमारी र भुँडे यती (२०७४) उपन्यास काल्पनिक छ। पृथ्वीका विभिन्न जीवजन्तु मात्र होइन काल्पनिक राजकुमारीको पनि उपस्थिति रहेको यस बालउपन्यासको मुख्य बालपात्र पिन्टोले विपनामा भएका पशुपंक्षी र सपनामा देखिएका कतिपय पशुपंक्षी एउटै पनि छन् । पिन्टोले अर्धचेतन तथा अवचेतन मनमा भएका पशुपंक्षीलाई सपनामा देखेको छ। यस्ता काल्पनिक सन्दर्भ बालमनोविज्ञानका विशेष पक्ष हुन्। विपनामै पनि बालबालिकाहरू विविध किसिमका कल्पना गरेर रमाएका हुन्छन् र तिनलाई सपनाले पनि साथ दिएकै हुन्छ भन्ने मान्यता यहाँ प्रस्तुत गरिएको छ।

ओहो ! मेरो प्यारो भाइ! मलाई सुरक्षित महसुस गर्न मेरो घर र बाआमाको सम्कना मात्र पनि पर्याप्त थियो। मेरो दुर्भाग्य ! आकाश पनि धुम्मियो । यतीले मलाई खाने दाउमा मुख 
बायो। बाँच्नु यत्ति नै रहेछ। मैले सोचें। ठिक यही समयमा ढक् ढक् गरेको सुनें। 'पिन्टो ढोका खोल ! मैले तिम्रो लागि समोसा बनाएर ल्याएको छु।' आमाले भन्नभयो। (खड्का, २०७४, पॄ. ४६)

माथिको उदाहरणमा पिन्टोले राजकुमारी, घोडा, यती, लोखर्के, ढुकुर आदि पशुपंक्षीलाई सपनामा देखेको छ, । घोडामा चढेको छ। राजकुमारीसंगै उडेको छ। यस्ता घटना सबै सपनामा देखेको छ। उसले सपनामा देखेको कठिन दृश्य वा अवस्थाबाट मुक्ति पनि चाहेको छ। ऊ भाइ तथा बुबाआमासँग भेट्न चाहेको छ सपनामै। ऊ सपनामै विचरण गरिरहँदा आमा कोठाभित्र पसेपछि, ब्युँकिएको छ।

कपिलमणि ज्ञवालीको कालो पाटी (२०७६) उपन्यासमा बालमनोविज्ञानको सन्दर्भ सचेतनामूलक किसिमले प्रस्तुत गरिएको छ।

मैले भनेकै त हो नि अर्काको घरमा जाने छोरीलाई पढाएर कुनै फाइदा छैन भनेर। के के न गर्ली भनेर भर्ना गरिदिनुभयो, खालि नोक्सान मात्रै। घरमा बसेको भए काममा त सघाउँथी । ... त्यसो हो भने भोलिदेखि स्कुल नपठाउने । कसका छोरीले पढेर बाउआमालाई सुख भएको छ र ? ... सुनैना जबर्जस्ती स्कुल जान खोजी। सविताले उसलाई जगल्ट्याएर कोठामा लगिन् र बाहिरबाट ढोका बन्द गरिदिइन् । सुनैना खुब रोई (ज्ञवाली, २०७४, पृपृ. ६०-६१)

माथिको उदाहरणमा अभिभावकबाट लैड़गिक विभेद भोगिसकेकी र आफूले गरेको आग्रहपछि, विद्यालय जान पाएको घटना सुनैनाका लागि ताजै थियो। अक आमाबाट हिंसाजन्य व्यवहारसमेत भोगेकी हुनाले सुनैनाको मनमा आफ्नो पढ़ने चाहना बिचैमा टुट्छ कि भन्ने पिरलो पनि बाँकी नै थियो। विद्यालयबाट फकंदा बाटोमा लडेर कालो पाटी फुटेपछि उनी निकै दु:खी भइन् । राती सपनामा त उनले विद्यालय छोड्न बाध्य पारिएको अवस्था देखिन् । उपन्यासकारले बालमस्तिष्कमा गहिरो चोट पुग्ने गरी पीडाबोध भएमा त्यसको असरले बालमनोविज्ञामा असर गर्ने सड्केत पनि गरेका छन्। सुनैनाले आफूमा रहेको पीडा, शड्का तथा चाहनालाई सपनामा देखेकी छन्।

ललिता दोषीको नीलकमल (२०७६) उपन्यासमा बालमनोविज्ञान र सामाजिक परिवेशलाई प्रभावकारी तरिकाबाट उठान गरिएको छ। बालबालिकाले कल्पनासँग सम्बद्ध र अर्धचेतनसँग सम्बद्ध सपना मात्र देख्दैनन् आफूले भोगेका घटनाले मनमा पारेको सकारात्मक र नकारात्मक छापका कारण पनि सपना देख्छन् । हुन त बालबालिकाका मात्र होइन सबै प्रकारका मानिसका सपनाको प्रकृति एवम् स्रोत उस्तै हुन्छन् । उपन्यासमा सपनालाई सबल किसिमले प्रस्तुत गरिएको छ।

नीला निद्रामा बर्बराएपछि राधाको ध्यान त्यतै गयो। 'ऐया ऐया, नपिट्नोस, म राम्रोसँग काम गई्छु, बिन्ती ! मेरो मालाई केही नभनिदिनोस् फेरि माले पिर गर्नुहुन्छ। बिन्ती नपिट्नोस् बिन्ति ......।' (दोषी, २०७६, पृ. ช०)

माथिको उदाहरणमा बालउपन्यासमा आफ़नी आमा राधाको हात शोभाले भाँचिदिएका कारण अशक्त बनेकाले उनले काम गर्ने वा भाँडा माक्ने घरमा बालिका नीला गएकी छन्। त्यो कुरा आमालाई थाहा छैन। 
नेपाली बालउपन्यासमा प्रस्तुत सपनाको विश्लेषण/ 143

नीलालाई काम गर्ने क्रममा लठ्ठीले हिर्काइएको कुरा सपनामा कराएपछि मात्र राधाले थाहा पाउँछिन् । पीडाले बालमानसिकतामा पार्ने प्रभाव र त्यसलाई सपनामा देखेको विषयलाई उपन्यासमा प्रस्तुत गरिएको छ।

\section{निचोड}

नेपाली बालउपन्यासमा सपनाका विभिन्न विषयवस्तु तथा परिवेशसहित बालमनोविज्ञानलाई सशक्त किसिमले उद्घाटन गरिएको छ। नेपाली बालउपन्यासका सड्ख्या धेरै नभएको वर्तमान अवस्थामा मौलिक नेपाली बालउपन्यासको सड्ख्या पनि कम रहेको पाइएको छ। थौरै सड्ख्यामा रहेका नेपाली मौलिक बालउपन्यासमा बालमनोविज्ञानका पक्ष त कुनै न कुनै रूपमा समावेश छन् तर सपनाका सन्दर्भ अत्यन्त न्यून सड्ख्याका प्रयुक्त छन् ।

नेपाली बालउपन्यासमा मनोविज्ञानको प्रमुख पक्ष मानिएको सपनाका विविध सन्दर्भ उठान भएका छन् । बालबालिकाहरूका चाहना तथा इच्छा अनेक हुन्छन्। उनीहरूले कल्पना गरेका, सुनेका या पढेका घटना, वस्तु, प्राणी या परिवेश वास्तविकतामै प्राप्त गर्ने चाहना राख्छन्। भौतिक संसार तथा आफ्नो वातावरणमा अप्राप्य वस्तु तथा विषयका बारेमा पनि उनीहरू जानकार हुँदैनन् । सामाजिक तथा पारिवारिक संरचना एवम् आर्थिक अवस्था आदिका कारण पनि बालबालिकाहरूले चाहेका विषय या वस्तु प्राप्त गर्न सक्दैनन्। यस्तो अवस्थामा उनीहरू सपनाका माध्यमबाट इच्छापूर्ति गई्छन्। आफूले भोगेका पीडा तथा अपमानको पनि बदला सपनामा नै लिएर सन्तुष्ट पनि हुन्छन् । विविध घटना एवम् परिवशका कारण बालबालिका भय एवम् डरत्रास उत्पन्न हुँदा पनि उनीहरू सपनामै कस्किन्छन् । बाबुआमा एवम् अभिभावकले गरेका विभेद एवम् उपलब्ध गराउन नसकेका वस्तु पनि सपनामै प्राप्त गर्न पुग्छन् । साथीहरूबिचका प्रेम, ईर्प्या, खुसी, रिस आदि संवेग पनि बालबालिकाले सपनामा देखेका हुन्छन्। यसरी नेपाली बालउपन्यासमा सपनाका विविध सन्दर्भलाई समावेश गरी बालमनोविज्ञानको सघन उद्घाटन गरिएको पाइन्छ।

\section{सन्दर्भ सामग्रीहरू}

अनुराधा (२०७३), मेरो कथाको एलियन, काठमाडौं : काठमाडौं पब्लिकेसन ।

एटम, नेत्र (२०७४), सङक्षिप्त साहित्यिक शब्दकोश, काठमाडौं : नेपाल प्रज्ञा प्रतिष्ठान ।

कसजू, विनयकुमार (सम्पा.), (२०७४), प्रज्ञा बालसाहित्य विवेचना, काठमाडौं : नेपाल प्रज्ञा प्रतिष्ठान ।

खड्का, उज्जलविक्रम (२०७४), पिन्टो, राजकुमारी र भुँडे यती, काठमाडौं : काठमाडौं पब्लिकेसन ।

खड्का, शर्मिला (२०६०), सानी, नेपाल : तेजबहादुर दाहाल ।

गेनारो/Gennaro L, Cipolli C, Cherubini A, et al. Amygdala and hippocampus volumetry and diffusivity in relation to dreaming. Hum Brain Mapp. 2011;32(9):1458-70. doi:10.1002/hbm. 21120 २०७७०दा२७ मा प्राप्त

घिमिरे, ध्रुवकुमार (२०७४), वालसाहित्यको विधागत सिद्धान्त र नेपाली वालसाहित्य, काठमाडौं : नेपाल प्रज्ञा प्रतिष्ठान ।

घिमिरे, ध्रुवकुमार (२०७४), बालसाहित्य : केही सैद्धान्तिक विमर्श, काठमाडौं : हिमालय बुक स्टल । 
जाङ/Zhang W, Guo B. Freud's dream interpretation: A different perspective based on the self-organization theory of dreaming. Front Psychol. 2018;9:1553. doi:10.3389/fpsyg.2018.01553 २०७७०६।२७ मा प्राप्त

ज्ञाली, कपिलमणि (२०७४), कालो पाटी, काठमाडौं : एडुकेसनल पब्लिसिड हाउस ।

टाइसन, लुइस (सन् २०१०), क्रिटिकल थ्योरी टुडे, न्युयोर्क : रट्लेज ।

तामाड, नेत्र (२०७३), बोजराज र बाउन्ने, काठमाडौं : कथालय इन्क ।

दोषी, ललिता (२०७६), नीलकमल, काठमाडौं : स्वदेश प्रकाशन प्रा.लि. ।

पराजुली, रज्जुश्री (२०६६), नेपाली बालसाहित्यको नालीबेली, काठमाडौं : विवेक सिर्जनशील प्रकाशन । प्रधान, प्रमोद (२०६९), नेपाली वालसाहित्यको इतिहास, काठमाडौं : शिखा बुक्स ।

बैर्ड/Baird B, Mota-Rolim SA, Dresler M. The cognitive neuroscience of lucid dreaming. Neurosci Biobehav Rev. 2019;100:305-323. doi:10.1016/j.neubiorev.2019.03.008 २०७९०६।२७ मा प्राप्त बराल, कृष्णहरि (२०६६), मनोविश्लेषण र साहित्य, काठमाडौं : अक्सफोर्ड इन्टरनेसनल पब्लिकेसन । भण्डारी, कृष्णप्रसाद (२०४६), फ्रायड र मनोविश्लेषण, ललितपुर : साका प्रकाशन ।

रिजाल, नवराज (२०६७), रोजीको हवाईजहाज, काठमाडौं : प्रज्ञापन प्रकाशन ।

रेग्मी, मुरारीप्रसाद (२०६५), मनोविश्लेषणात्मक समालोचना, ललितपुर : साभा प्रकाशन ।

वलट/Vallat R, Ruby PM. Is it a good idea to cultivate lucid dreaming? Front Psychol. 2019;10:2585. doi:10.3389/fpsyg.2019.02585. २०७७०५।१९मा प्राप्त

वाग्ले, अनन्त (२०७२), यार्चा, काठमाडौं : काठमाडौं पब्लिकेसन ।

श्रेष्ठ, कविताराम (२०४९), मावलीको यात्रा, ललितपुर : साभा प्रकाशन ।

सिद्देल, कृष्णदीप (२०७३), चोरी भो जुत्ता, काठमाडौं : हिमालय बुक स्टल ।

स्क्रेड्ल/Schredl, Michael, https://pubmed.ncbi.nlm.nih.gov/20870066/\#affiliation-1, DOI : 10.1016/S0074-7742(10) 92007-2 २०७७०९।२१ मा प्राप्त

स्टम्ब्रेस/Stumbrys T, Daunyte V. Visiting the land of dream muses: The relationship between lucid dreaming and creativity. 2018;11(2). doi:10.11588/ijodr.2018.2.48667 २०७७०६।O१ मा प्राप्त

होरिकावा/Horikawa T, Tamaki M, Miyawaki Y, Kamitani Y. Neural decoding of visual imagery during sleep. Science. 2013;340(6132):639-42. doi:10.1126/science.1234330 २०७७०६।२प मा प्राप्त

https://www.sleepassociation.org/about-sleep/dreams/ २०७७१०१२७ मा प्राप्त https://courses.lumenlearning.com/wmopen-psychology/chapter/reading-dreams/ २०७७०९।१९ मा प्राप्त https://www.verywellmind.com/why-do-we-dream-top-dream-theories-2795931.२०७७१०००४ मा प्राप्त 